\section{Research Article}

(c) 2021 Sariwulan et al. This is an open access article licensed under the Creative Commons Attribution-NonCommercial 4.o International License (https://creativecommons.org/licenses/by-nc/4.o/)

Received: 22 March 2021 / Accepted: 27 July 2021 / Published: 5 September 2021

\title{
Impact of Employee Talent Management
}

\author{
Tuty Sariwulan ${ }^{1 *}$ \\ Suyono Thamrin ${ }^{2}$ \\ Mukmin Suyatni ${ }^{3}$ \\ Iskandar Agung ${ }^{4}$ \\ Ferdi Widiputera $^{4}$ \\ Arie Budi Susanto 4 \\ M. Calvin Capnary 5 \\ ${ }^{1}$ Faculty of Economy, Jakarta State University, Jakarta, Indonesia \\ Jln. Rawamangun Muka, rawamangun, Jakarta, Indonesia \\ ${ }^{2}$ Faculty of Defense Management, Indonesia Defense University, \\ Jl. Sentul - Citeureup, Sentul, Kec. Citeureup, Bogor, Jawa Barat 16810, Indonesia 24 \\ ${ }^{3}$ Economic and Business Faculty, Mataram University, Indonesia. \\ Jl. Majapahit No.62, Gomong, Kec. Selaparang, Mataram City, West Nusa Tenggara Barat, Indonesia \\ ${ }^{4}$ Center for Policy Research, Ministry of Education and Culture, \\ Building E, 2nd Floor, Jalan Jenderal Sudirman, Senayan, Jakarta Pusat, DKI Jakarta 1219o, Indonesia \\ ${ }^{5}$ Bina Nusantara University, Kebon Jeruk, Jakarta, Indonesia \\ Jl. Kebon Jeruk Raya No. 27, Kebon Jeruk, West Jakarta, Indonesia \\ *Correspondence Author
}

DOI: https://doi.org/10.36941/ajis-2021-0133

\begin{abstract}
This study aimed to analyze the factors that influence employee talent management and their impact on job satisfaction, job performance, and commitment sustainability. The study was conducted on workers in five companies located in Karawang Regency (pallet plastics, automotive, and hospitality industries) and Bogor (garment industry) located in the province of West Java, and South Tangerang (heavy tractor industry). This sample of respondents will answer the questionnaire in the questionnaire.) in Banten province. Data collection was conducted through questionnaire sharing with a sample of 250 employees, as well as interviews and focus group discussions (FGD) with a number of stakeholders. Questionnaires before being applied in field studies were examined using Pearson and Cronbach Alpha approaches in order to identify the level of validity and reliability. The analysis of the research was conducted using Structural Equation Modeling (SEM) approach with the help of the Lisrel 8.70 program. The results show that organizational culture factors, transformational leadership, and job sharing have a positive impact on employee talent management, and talent management itself has an impact on job satisfaction, job performance, and commitment sustainability. It is recommended in the development of this talent-based workforce that the above factors should be considered along with the highest contributing factors to each factor.
\end{abstract}

Keywords: leadership, division of work, talent, satisfaction, performance, sustainability 


\section{Introduction}

Talent-based employee recruitment has received little attention in any work organization, either government or private. Much of the recruitment of workers in these two institutions is often based on educational background (diploma), kinship, nepotism, or low wages, not because of their talent. As a result, the work situation tends to be passive, less independent, less productive, less creative, and less concerned with organizational performance. Such a work environment certainly does not support progress and threatens the survival of the organization. In the case of civil servants at central and regional government agencies, for example, recruitment is less responsive to the element of talent, resulting in less competent and professional workers, thus less productive and efficient. While the government is in compliance with regulations that gradually increase wages and jobs. Similar situations occur in the private sector that emphasize the recruitment of low-paid, low-skilled, and professional workers, resulting in lower productivity, loss, and (possibly) threatening business continuity.

Recently, the talent aspect of government and the private sector is gaining momentum. Recruitment and talent development efforts have taken a serious interest recently in the government and private sector. Recruitment and talent development efforts have taken a serious interest in producing competent and professional staff. Attention to talent is expected to bring personal pleasure and appreciation for work, thereby constantly developing competence and professionalism. In the government sector, for example, the ministry of state apparatus and bureaucratic reform Republic of Indonesia has been working to develop talent management to enhance the competency and productivity of the State Civil Apparatus (SCA) across all agencies. Governments perceive the need for optimal talent management in an efficient, competitive and competent human resource (HR) effort. The goal of national talent management is to recruit the best talented employees working with government agencies to drive accelerated development (Ministry of Administrative and Bureaucratic Reform, 2019). Bashori (2012) argues that talented civil servants need to be managed in an unusual way, to detect, develop, and use the acquired talent to more effectively achieve their personal and organizational goals. The same is true of the private sector seeking to develop the talent of its employees. Of course, the goal is to produce competent and professional workers who can bring high-performance organizational performance, excel in business competition, reap the benefits, and maintain long-term business sustainability. Various studies have shown the relationship between employee talent development and corporate performance. Fatmasari (2017), Octavia and Susilo (2018) and Irawati, Sudarsono, dan Lestari (2017) for example shows that talent management has a positive and significant impact on employee performance.

Emphasizing the workforce needs to be systematically managed, directed, and effective in order to improve the organization, as well as develop the competence and professionalism of the workforce itself. Employee talent management can be the gateway to business performance and growth, where employees are happy, passionate, loyal, committed, high work productivity, and ultimately positively impact organizational and business sustainability. It is not surprising that various parties have turned their attention to the talent management of their employees as one of the humanitarian aspects of achieving their organizational goals. But talent management is influenced by a number of factors, including: organizational culture, leadership, division of labor, dynamic capabilities, and competitive advantage. Therefore, it is important to know how these factors affect the management of the worker's talent. Understanding the influence of Reviews These factors is expected to bring the effort required to develop the talent of the workers. Additionally, it is important to know how talent management affects the workforce itself, especially when it comes to job satisfaction, performance, and commitment to work continuity, loyalty, and passion.

The latter is intended to analyze the factors that influence talent management, and the impact on workers. Factors Influencing talent management that will be the focus of the study are organizational culture, leadership, division of labor, dynamic capabilities, and competitive advantage, while the impact of talent management includes factors on job satisfaction, performance, and employee commitment. 


\section{Literature Review}

Below are the conceptual limitations of the variables that are the focus of the research.

\subsection{Culture Organization}

The organization can be defined as a group of people working together to achieve the goals and objectives of the organization. Within the organization are social relations and division and allocation of work,

Business organizations need to renew their competencies job coordination, member recruitment, employee motivation, and resource allocation and use for organizational sustainability (see: Weber, 1968; Buchanan, 1977; Dahl, 2003, Usman, 2006; Agung, 2010).

An organization as an organized social group supports its own culture in achieving its goals and objectives. Social scientists do indeed give different definitions of this culture, according to their own point of view. Pettigrew (2015) argues that organizational culture is an integral part in an activity that has collective meaning in a particular group at a certain time.. Sathe interpreted as a set of important assumptions (often unstated) that members of a community share is common. Davis (2004) defines "...patterns of belief and values that give members the meaning of a common institution, and the existence of rules that have been established for the mutual benefit". Schein (2014) states that "...the basic assumptions pattern approach in solving problems in adapting and integrating externally and internally and obviously considered to be valid, so it is necessary to be educated on how to perceive, think and feel in this particular of situation.".

From the definition presented above it can be concluded that organizational culture is a set of values, beliefs, rules, and the like that are shaped by its members in establishing behaviors to achieve organizational goals. Control behavior of its members to achieve their goals and objectives. In this paper a set of values is limited to work ethic, hard work, discipline, and rules regarding system rewards.

\subsection{Transformational Leadership}

Many opinions on leadership are expressed by management and organizational experts. But it can be concluded that leadership is related to the process of social influence which is the deliberate effect of organizing activities and achieving common goals. Leadership is the process of influencing and moving an individual or group of people toward a shared goal. Thoha (2008) argues that leadership is an activity that influences the behavior of others, or the art that influences human behavior both individually and in groups. In other words, leadership is the science and art of influencing others or groups to act as intended to achieve a common and effective goal. According to Anderson (2016) his ideas on transformational leadership mean the ability of a person with vision, planning, communication, and creative action to positively impact a group of people in a clear set of values and beliefs to achieve a clearly defined and measurable goal. Luthans (2002) and Nanus (2004) describe the traits of transformational leadership, namely: future vision, identifying himself as an agent of change, daring to take risks, trusting others, acting on value systems and not on the basis of individual interests, continuing to improve abilities. throughout life, and the ability to deal with complex, vague, and uncertain situations.

In this paper the characteristics of transformational leadership refer to four (four) indicators, namely: visionary, change agent, risk taking, and transparent and democratic. Visioner refers to the idea that one of the functions of a leader is to create a shared, credible, credible, and exciting vision for the organization. In everyone's mind, a vision can be taught and created by a leader or subordinates (Yukl, 2012). Visionary leaders must act as agents of change, fully oriented to results, adopt challenging new visions, communicate visions and influence others, and seek the support and enthusiasm of workers to realize that vision. For this reason all leaders must also take risks to make 
changes and achieve their organization's progress. Organizational leadership must also be transparent and democratic, to open up all the data and information that subordinates need to advance the organization and leaders must be open to the opinions and criticisms of their subordinates (see also: Nanus, 2001).

\subsection{Division of Work}

Formal organizations usually have a clear structure that regulates the position and role of a person or group of people and work relationships with each other. Organizational structure is also one way to make adjustments and strategies in achieving goals and objectives (Pennings, 1992). The structure also includes the division of labor which contains a job analysis in determining what position and who is carrying out the work. Claudia (2020) suggests that the division of labor is a task assigned to, and completed by a person or group of workers to improve efficiency. The division of labor is also known as the breakdown of tasks that are different from each other. This means that for each job there are a number of processes that must be performed in order for the work to be completed. Hasibuan (2011) argues that the division of labor is written information that outlines the duties and responsibilities, working conditions, employment relationships, and aspects of work at certain positions in the organization. According to Roring (2017), the division of labor in a company is proven to affect employee performance.

In this paper the division of labor includes indicators of job description, working conditions, employment relationships, and trust. Job description relates to job function, working conditions related to the work situation achieved, work relationship refers to the situation of work social relations, and trust is the trust given to a person or group of people in carrying out work.

\subsection{Dynamic Capacity}

Dynamic capabilities can be understood as the company's ability to renew its competence so that the company is able to achieve competitive advantage all the time and survive in the turbulence of the business environment (Cao, 2011). This capability is called dynamic capability, which is the organization's effort to integrate, build and reconfigure internal and external capabilities in line with the rapid changes in the environment and to achieve compliance with these changes (Teece, et al, 1997). Eisenhardt's and Martin (2000) define it as a business process in a company that uses its resources specifically the process of integration, reconfiguration, obtaining and releasing resources to adjust or create market changes, organizational skills, resources and competence for change. Helfat et al (2007) argues as the capability of the organization that aims to create, expand or modify resource-based.

The point is dynamic capacity is the ability of organizations to achieve new forms by developing competitiveness through renewal of human and material resources. Teece et al (1997) and Eisenhardt and Martin (200o) state that a company's dynamic ability to reconfigure human and material resources. Pavlou \& Sawy (2011: 239-273) identify dynamic abilities into four dimensions, namely: sense ability (sensing capability) is the ability to recognize, interpret and pursue opportunities in the environment; learning ability, which is the ability to change existing operational capabilities with new knowledge; integrated capabilities, namely the ability to transform existing operational capabilities with new knowledge into new operational capabilities by creating shared understanding with collective common sense; and coordination capabilities, namely the ability to manage and use tasks, resources, and activities in new operational capabilities. In this paper dynamic capacity variable indicators only cover the dimensions of sensing capacity, learning capacity, and coordination capacity. 


\subsection{Advantage Competitive}

Dynamic capacity is closely related to developing competitive advantage. According to Kotler \& Armstrong (2001), competitive advantage is excellence by offering more value to consumers, either through lower prices or by providing more benefits. Porter (1998) defines competitive advantage as the ability of companies to achieve economic benefits compared to the benefits that can be achieved by competitors in the market in the same industry. According to Barney (1991), competitive advantage aims to form a barrier and competitors cannot imitate, so the company can achieve benefits from its resources. Every company that has a competitor in an industrial environment has a desire to be superior compared to its competitors.

In general, companies implement competitive strategies to have an advantage in resources and expertise. Implicit competitive advantage requires companies to have competent and professional human resources. The ability to develop employee skills well will make the company excel in implementing strategies based on human resources and difficult for competitors to imitate. Various studies show the importance of managing and developing employee talent to produce competent resources and have a competitive advantage (Bharadwaj, Varadarajan and Fahy, 1993; Day and Wensley, 1988). Competitive advantage is related to cost advantage, product differentiation, and target market segments.

\subsection{Employee Talent Management}

Talent can be defined as a character trait that a person has from birth. Talent development will bring competence in carrying out their duties happily and with excitement. Therefore, talent management is crucial for a business organization to acquire the skills and expertise of its employees to support the achievement of corporate goals. Talent management is a systematic way of incorporating elements of planning, organizing, implementation, and evaluation, with the aim of producing competent and effective human resources, so that organizational goals can be achieved. Gasperz (2013) states that talent management is a human resource management process associated with three main processes, namely: developing and strengthening employees when they first enter the organization, retaining and developing existing employees, and attracting as many employees as possible. That has the competence, commitment, and character to want to work in the company. Baum (2008) argues that talent management is an organizational mindset in ensuring that the right talent is available for the right job and at the right time based on the strategic goals of the business. Or Silzer and Dowell (2009) argue that talent management is a series of integrated processes and procedures that organizations use to attract, retain, develop, and mobilize talent to achieve the organization's strategic goals.

Amstrong and Baron (2005) present the benefits of talent management for a company, among others: improving the recruitment and selection process so that the organization / company acquires high quality talent; provide a more competitive and fair package of renumeration; perform risk analysis, such as identifying potential employees, conserving employee turnover; enhancing learning and development programs to improve future performance and competence; and perform internal screening to identify potential employees. On the employee side, the benefits are to increase motivation and commitment, develop careers, increase knowledge about contributing to the company's goals and increase job satisfaction.

In this paper efforts to manage the talent of workers will be seen through the indicators of identification of workforce, education and training provision, job placement, and needed support. The point is that efforts to manage workers 'talent must be able to identify workers' talents, design education and training programs in the right manner, develop their placement competencies and accuracy, and provide the necessary facilities support to produce creative and productive employees. 


\subsection{Job Satisfaction}

Someone will judge whether or not satisfied with their work. The level of satisfaction can be high or low depending on the aspects received from the workplace. Luthans (2002) argued that the level of job satisfaction of a person is directly proportional to the level of performance and vice versa. Correspondingly, some experts suggest that job satisfaction is a positive feeling towards the work, on the contrary dissatisfaction is a response to negative feelings towards work and / or workplace (Robbins and Judge, 2007; Vecchio, 1995; Greenberg and Baron, 2003; Wibowo, 2007). Kirkpatrick and Levis (1995) described that a person feels job satisfaction can be recognized to several factors, i.e., job challenges, peer relations, promotion opportunities, the amount of compensation, the supervisory mechanism and the work environment.

Talent management is expected to build employee competence and impact employee satisfaction. Lei, Basit, and Hasan (2018), Dixit and Arrawatia (2018) show the influence of talent management on employee satisfaction levels. Various studies show that job satisfaction also influences other sub-aspects of work as described by Bakan et al (2014), Shaju and Subhashini (2017), and Darmawati et al (2013). In this paper we will look at the impact of talent management on job satisfaction through indicators of income levels, career assurance, and fulfillment of workforce guarantees, such as: leave, health insurance, and more.

\subsection{Job Performance}

Performance is often associated with results achieved. Sucipto (1997) and Robbins (2006) suggest that success in doing a job is strongly determined by performance. Mathis and Jackson (2006) say performance is essentially an activity that is done or not performed by the individual. This is why performance behaviors are important to observe and to achieve organizational goals. On that basis, many organizations / companies periodically conduct performance evaluations to reflect the performance of their members / employees. Performance appraisals provide feedback on important decisions, such as promotions, job shifts, and even termination of employment. Performance appraisals are also useful for identifying training and development needs, demonstrating staff skills and competencies, providing staff feedback on their performance, as a basis for allocating rewards, and so on.

The application of talent management is often based on the assessment of members / employees so that the organization / company can achieve its goals. Talent management is intended to have an impact on employee performance, enabling the organization / company to maintain longterm sustainability. For corporate organizations talent management efforts are expected to increase productivity, provide benefits, and compete with competitors, and last longer. In this paper, worker performance is viewed in terms of job quantity, job quality, and job productivity punctuality.

\subsection{Commitment Sustainability}

Employees must be required to have a commitment to the organization where they work, so that it can bring progress to the company and himself. Meyer and Natalie (2002) argue, organizational commitment is defined as the desire on the part of employees to remain members of the organization. According to Robbins (2011) argues, organizational commitment is the extent to which employees identify with the organization and want to maintain membership in the organization. The same opinion was expressed by Colquitt, Lepine and Wesson (2014) and Luthans (2002) which they defined organizational commitment is the situation of employees in the organization membership and having commitment. One of those commitments is regarding the sustainability of employees to keep working in their workplaces.

Sustainability commitment refers to the employee's view of work in the company that encourages morale, hope, and desire to survive or leave the company. Employees assume 
sustainability in their company is caused by their need for the company, otherwise it will result in losses if they leave. According to Allen and Meyer (1996), employees who are committed to working in the organization will receive more benefits. With a strong commitment, it encourages employees to be dedicated, enthusiastic and work with high levels of productivity.

\subsection{Theoretical Framework}

From the above description is developed a theoretical framework to approach and analyze the research problems.

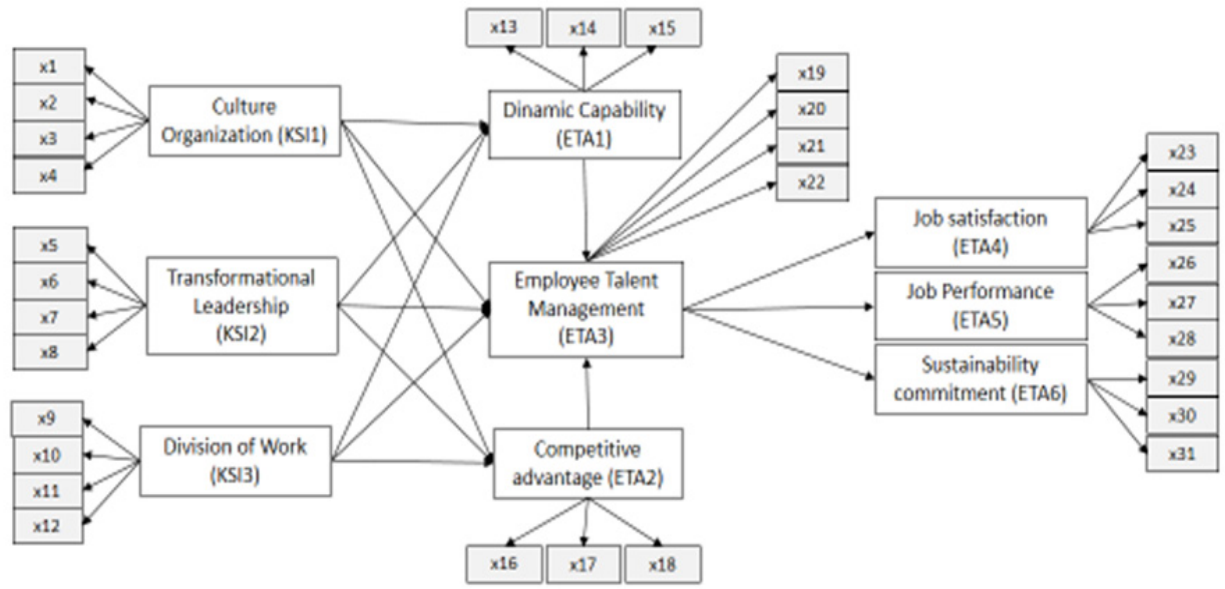

\begin{tabular}{|c|c|c|c|c|c|c|c|c|}
\hline \multicolumn{9}{|l|}{ ription: } \\
\hline KSI1 & KSIs & KSI3 & ETA: & ETAs & ETAS & ETAt & ETAS & ETA6 \\
\hline Putaritso & ม - Vhaianes & 20 - Wowk cenditicen & 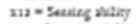 & nte $=$ Cont 2 alatap & zu = Tuest Lesthation & 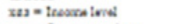 & see - puesity & aes $=1$ - \\
\hline $\begin{array}{l}\text { toceplins } \\
\text { ind woek }\end{array}$ & 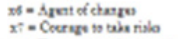 & 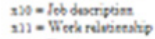 & $\begin{array}{l}\text { 21, - Learning inlity } \\
\text { xis = Cocondeatiog }\end{array}$ & 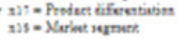 & 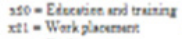 & $\begin{array}{l}\text { xts - Carver certsint } \\
\text { xts - Fulfilnert of nyth }\end{array}$ & $\begin{array}{l}\text { st7 = Quality } \\
\text { xass - Pescouling }\end{array}$ & 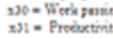 \\
\hline trroet rpoces & 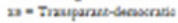 & sat = trus & & & ut = r×Lity ufpurt & & & \\
\hline
\end{tabular}

Figure 1: Study impact of employee talent management

The research hypothesis proposed:

- Culture Organization (KSI1), Transformational Leadership (KSI2), and Division of Work $\left(\mathrm{KSI}_{3}\right)$ have an influence on Dynamic Capability (ETA1), Competitive Advantage (ETA2) and Employee Talent Management (ETA3);

- Dynamic Capability (ETA1) and Competitive Advantage (ETA2) have an influence on Employee Talent Management (ETA3);

- Employee Talent Management (ETA3) affects Job Satisfaction (ETA4), Job Performance (ETA5), and Sustainability Commitment (ETA6).

\section{Methodology}

\subsection{Sample Location}

The study was conducted in early 2020 by locating five (5) companies in the Karawang and Bogor areas of West Java Province, and South Tangerang in Banten Province. Sample companies in Bogor District are moving in the convection area, Tangerang City is moving in the heavy equipment industry, and Karawang District is moving in the plastics, automotive, and hospitality industries. The selection of a sample of company samples was done randomly with the main consideration of the 
business organization having a relatively large number of workers.

\subsection{Sample Respondent}

Of the five sample companies obtained a sample of respondents using random but not identical techniques. A sample of 250 employees comprised of 50 workers in the plastic pallet, garment and heavy tractor industry, 70 automotive industry workers and 30 hospitality industry workers. This sample of respondents will answer the questionnaire in the questionnaire.

\subsection{Data Collection and Analysis Techniques}

The data was collected by distributing questionnaires to employees and then conducting interviews and focus group discussions. Especially the questionnaire before being used in the research was conducted to test its validity and reliability. The criterion used was Pearson's correlation coefficient and Cronbach's alpha. Analysis using Structural Equation Modeling (SEM) using the Lisrel 8.70 program (Hair, 2004; Haryono and Wardoyo, 2012).

\section{Findings}

\subsection{Characteristic Respondent}

The results of the distribution of the questionnaire showed that $164(65.60 \%)$ were filled by male respondents and $84(34.40 \%)$ were female respondents. The age distribution of respondents starts from the lowest of 17 years and the highest of 52 years, with the most categories at the age of 30-40 years. Work experience in the company is currently distributed from not reaching one year (12.08\%), less than 10 years $(65.12 \%)$ and more than 10 years $(22.08 \%)$. A total of $210(84.00 \%)$ respondents were married, while 40 (16.0o) percent had never been married. A small proportion (21.20\%) of respondents said that they live in a rented house alone or with others, and $78.80 \%$ of respondents live with their families.

In terms of income level, significant differences are accepted by respondents, depending on their status and work skills. Employees working with low skill levels earn salaries in the range of less than IDR 5 million - IDR 10 million per month based on regional minimum wages (the amount varies between provinces) plus incentives for overtime. Most skilled employees get wages above 10 million 20 million rupiah, and some employees get salaries above 20 million rupiah (currently USD \$ $1=$ approximately 15 thousand rupiah).

\subsection{Validity and Reliability}

Hair et al (2010) presented confirmatory factor analysis (CFA) to test the dimensions of constructs or variables. To test the validity and reliability, the CFA approach is used to differentiate indicator variables and latent variables (Haryono and Wardoyo, 2012, Zakso \& Agung, 2021; Yohana, Dania, \& Prihandono, 2021). The validity test is related to measuring the variable whether it is valid or not and it is to compare the loading factor value of 0.5 . The load factor value above 0.5 , the indicator is valid. In order for the measuring instrument to yield decent output, a reliability test is needed. Reliability value is measured by Construct Reliability (CR) and Variance Extract (VE). It assumed that the data will be reliable if the $C R$ value is above 0.70 and VE value is more than 0.50 (Zakso \& Agung, 2021). Table 2 shows the validity and reliability test results. 
Table 2: Validity and Reliability Test Results

\begin{tabular}{|c|c|c|c|c|c|c|c|c|c|c|c|}
\hline Indicators & SLF & ei & $\mathrm{Cr}$ & $\mathrm{Ve}$ & Conclusion & Indicators & SLF & ei & $\mathrm{Cr}$ & $\mathrm{Ve}$ & Conclusion \\
\hline $\mathrm{CO}$ (KSI1) & & & & & & CA (ETA2) & & & & & \\
\hline $\mathrm{X} 1$ & 0.79 & 0.37 & \multirow{4}{*}{0.909} & \multirow{4}{*}{0.716} & \multirow{4}{*}{$\begin{array}{l}\text { Valid \& } \\
\text { Reliable }\end{array}$} & $\mathrm{x} 16$ & 0.64 & 0.58 & \multirow{3}{*}{0.902} & \multirow{3}{*}{0.759} & \multirow{3}{*}{$\begin{array}{l}\text { Valid \& } \\
\text { Reliable }\end{array}$} \\
\hline $\mathrm{X} 2$ & 0.76 & 0.42 & & & & X17 & 0.99 & 0.03 & & & \\
\hline$x_{3}$ & 0.82 & 0.33 & & & & $\mathrm{x} 18$ & 0.94 & 0.11 & & & \\
\hline $\mathrm{x} 4$ & 0.99 & 0.01 & & & & TM (ETA3) & & & & & \\
\hline \multicolumn{6}{|l|}{ TL (KSI2) } & X19 & 0.90 & 0.19 & \multirow{4}{*}{0.929} & \multirow{4}{*}{0.766} & \multirow{4}{*}{$\begin{array}{l}\text { Valid \& } \\
\text { Reliable }\end{array}$} \\
\hline $\mathrm{x} 5$ & 0.88 & 0.22 & \multirow{4}{*}{0.944} & \multirow{4}{*}{0.807} & \multirow{4}{*}{$\begin{array}{l}\text { Valid \& } \\
\text { Reliable }\end{array}$} & $\mathrm{X} 2 \mathrm{O}$ & 0.81 & 0.35 & & & \\
\hline x6 & 0.88 & 0.22 & & & & $\mathrm{X} 21$ & 0.86 & 0.26 & & & \\
\hline $\mathrm{x} 7$ & 0.91 & 0.18 & & & & X22 & 0.93 & 0.14 & & & \\
\hline $\mathrm{x} 8$ & 0.92 & 0.15 & & & & JS (ETA4) & & & & & \\
\hline \multicolumn{6}{|l|}{ DoW (KSI3) } & \multirow{3}{*}{$\begin{array}{l}\mathrm{X} 23 \\
\mathrm{X} 24 \\
\mathrm{X} 25\end{array}$} & 0.58 & 0.67 & \multirow{3}{*}{0.824} & \multirow{3}{*}{0.618} & \multirow{3}{*}{$\begin{array}{l}\text { Valid \& } \\
\text { Reliable }\end{array}$} \\
\hline x9 & 0.60 & 0.64 & \multirow{4}{*}{0.863} & \multirow{4}{*}{0.626} & \multirow{4}{*}{$\begin{array}{l}\text { Valid \& } \\
\text { Reliable }\end{array}$} & & 0.81 & 0.34 & & & \\
\hline X10 & 0.55 & 0.70 & & & & & 0.93 & 0.14 & & & \\
\hline $\mathrm{X} 11$ & 0.97 & 0.06 & & & & JP(ETA5) & & & & & \\
\hline $\mathrm{X} 12$ & 0.95 & 0.10 & & & & $\mathrm{x} 26$ & 0.81 & 0.34 & \multirow{3}{*}{0.931} & \multirow{3}{*}{0.819} & \multirow{3}{*}{$\begin{array}{l}\text { Valid \& } \\
\text { Reliable }\end{array}$} \\
\hline DC (ETA1) & & & & & & $\mathrm{x} 27$ & 0.93 & 0.13 & & & \\
\hline $\mathrm{x} 13$ & 0.97 & 0.38 & \multirow{3}{*}{0.884} & \multirow{3}{*}{0.718} & \multirow{3}{*}{$\begin{array}{l}\text { Valid \& } \\
\text { Reliable }\end{array}$} & x28 & 0.96 & 0.07 & & & \\
\hline X14 & 0.80 & 0.36 & & & & CS (ETA6) & & & & & \\
\hline $\mathrm{X} 15$ & 0.95 & 0.11 & & & & \multirow{3}{*}{$\begin{array}{l}\text { X29 } \\
\text { x30 }\end{array}$} & 0.82 & 0.33 & \multirow{3}{*}{0.914} & \multirow{3}{*}{0.781} & \multirow{3}{*}{$\begin{array}{l}\text { Valid \& } \\
\text { Reliable }\end{array}$} \\
\hline & & & & & & & 0.94 & 0.12 & & & \\
\hline & & & & & & & 0.89 & 0.21 & & & \\
\hline
\end{tabular}

Source: Study impact of employee talent management

\subsection{Goodness of Fit (GOF) Model}

Before analyzing the structural model in SEM needs to perform conformance testing overall model is seen from LISREL output (Hair et al, 2006). The test results show whether the theoretical model is built is in conformity with the data, so as to meet the requirements of the analysis to determine the relationship between variables and indicators studied (Winingsih, Agung, \& Sulistiono, 2020). Overall, the summary of the critical values of the model suitability test is summarized in Table 3 .

Table 3: GOF Model Results

\begin{tabular}{|l|c|c|c|}
\hline Goodness-of-Fit & Cutt-off-Value & Value & Conclusion \\
\hline RMR (Root Mean Square Residual) & $\leq 0,05$ atau $\leq 0,1$ & 0.0210 & Good Fit \\
\hline RMSEA (Root Mean square Error of Approximation) & $\leq 0,08$ & 0.0297 & Good Fit \\
\hline GFI (Goodness of Fit) & $\geq 0,90$ & 0.99 & Good Fit \\
\hline AGFI (Adjusted Goodness of Fit Index) & $\geq 0,90$ & 0.98 & Good Fit \\
\hline CFI (Comparative Fit Index) & $\geq 0,90$ & 0.98 & Good Fit \\
\hline Normed Fit Index (NFI) & $\geq 0,90$ & 0.99 & Good Fit \\
\hline Non-Normed Fit Index (NNFI) & $\geq 0,90$ & 0.99 & Good Fit \\
\hline Incremental Fit Index (IFI) & $\geq 0,90$ & 0.99 & Good Fit \\
\hline Relative Fit Index (RFI) & $\geq 0,90$ & 0.98 & Good Fit \\
\hline
\end{tabular}

Source: Study impact of employee talent management

In table 3 show that the RMSEA is smaller than o.o8, CFI, IFI, NFI, RFI, and GFI get values greater than 0.90 , while AGFI shows values smaller than 0.90 . These results indicate that the model is good fit. 


\subsection{Structural Equation Results}

The study data that has been tested for validity and reliability are then processed to determine the relationship between variables and the contribution of indicators in each variable using the Lisrel 8.70 application. the results are as follows.

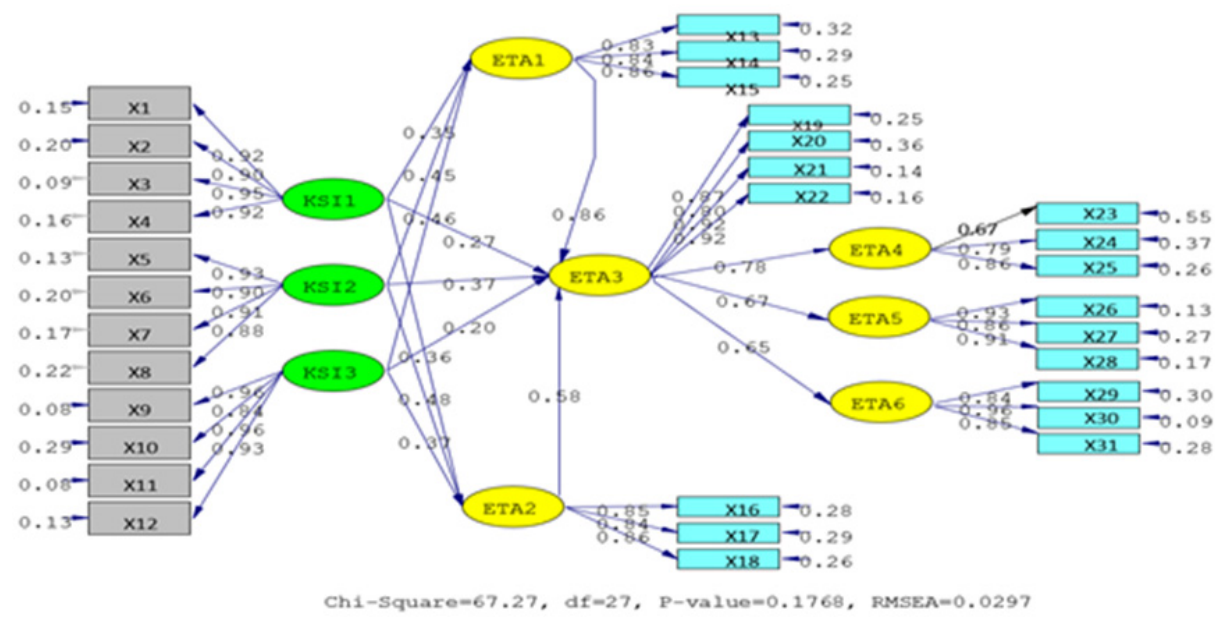

Figure 2. Standardized loading factor Study impact of employee talent management Source: Study impact of employee talent management

Based on the results above, it can be seen the results of testing the hypothesis of the studied variables. Table 4 below shows that the allegations raised in this study had a significant effect.

Table 4: Hypothesis Test Results

\begin{tabular}{|c|c|c|c|c|c|}
\hline \multicolumn{3}{|c|}{ Hypothesis } & Coef. & T-Count & Conclusion \\
\hline KSI1 & $\rightarrow$ & ETA1 & 0.35 & 8.76 & Significant \\
\hline $\mathrm{KSI}_{2}$ & $\rightarrow$ & ETA1 & 0.45 & 11.78 & Significant \\
\hline $\mathrm{KSI}_{3}$ & $\rightarrow$ & ETA1 & 0.46 & 11.03 & Significant \\
\hline KSI1 & $\rightarrow$ & ETA2 & 0.36 & $9 \cdot 35$ & Significant \\
\hline $\mathrm{KSI}_{2}$ & $\rightarrow$ & ETA2 & 0.48 & 12.94 & Significant \\
\hline $\mathrm{KSI}_{3}$ & $\rightarrow$ & ETA2 & 0.37 & $9 \cdot 37$ & Significant \\
\hline KSI1 & $\rightarrow$ & $\mathrm{ETA}_{3}$ & 0.27 & 11.33 & Significant \\
\hline $\mathrm{KSI}_{2}$ & $\rightarrow$ & $\mathrm{ETA}_{3}$ & 0.37 & 9.34 & Significant \\
\hline $\mathrm{KSI}_{3}$ & $\rightarrow$ & $\mathrm{ETA}_{3}$ & 0.20 & 11.23 & Significant \\
\hline ETA1 & $\rightarrow$ & $\mathrm{ETA}_{3}$ & 0.86 & 9.92 & Significant \\
\hline ETA2 & $\rightarrow$ & $\mathrm{ETA}_{3}$ & 0.58 & 10.22 & Significant \\
\hline $\mathrm{ETA}_{3}$ & $\rightarrow$ & ETA4 $_{4}$ & 0.78 & 40.21 & Significant \\
\hline $\mathrm{ETA}_{3}$ & $\rightarrow$ & ETA $_{5}$ & 0.67 & $33 \cdot 37$ & Significant \\
\hline $\mathrm{ETA}_{3}$ & $\rightarrow$ & ETA6 & 0.65 & 35.08 & Significant \\
\hline
\end{tabular}

Source: Study impact of employee talent management

Table 4 shows the positive influence of $\mathrm{KSI}_{1}, \mathrm{KSI}_{2}$, and $\mathrm{KSI}_{3}$ is stronger on ETA1 and ETA2 than ETA3. The transformational leadership variable (KSI2) has the most positive influence on employee talent 
management compared to organizational culture variables (KSI1) and work division (KSI3). From this result it appears that the leadership role is very important in managing employee talent, especially in supporting visionary views, acting as agents of change, acting transparently and democratically, giving trust to employees, and developing togetherness to achieve company progress (Nanus, 2004, Luthans, 2002, Anderson, 2016). Dahl (23) argues, "... traditional views often place leaders acting alone in setting goals and making decisions. Leadership today requires leaders / managers to learn to think about controlling with and not over others. Leaders control with others means building a relationship based on the same vision and achievement. A leader must be able to deeply analyze an overall system, evaluate the work of staff, become an agent of change and encourage staff to be more advanced".

On the other hand, the influence of KSI1, KSI2, and $\mathrm{KSI}_{3}$ indirectly through ETA1 and ETA2 shows that the influence of dynamic ability (ETA1) on ETA3 is greater than competitive advantage (ETA2). Many experts argue that dynamic capability is a source of competitive advantage (Froehlich, Bitencourt, and Bossle, 2017; Ambrosini and Bowman, 2009; Teece, 2007). Eisenhardt and Martin (2000), Wheeler (2002), and Helfat et al (2007) argue that building dynamic capabilities of business organizations aims to create, expand or modify resources to achieve competitive advantage, so companies must attract, strengthen, and reconstruct power competitiveness. Tight dynamic capabilities can be understood as the company's ability to renew its competence so that it can achieve competitive advantage at any time and survive in the turbulent business environment.

The influence of $\mathrm{KSI}_{1}, \mathrm{KSI}_{2}$, and $\mathrm{KSI}_{3}$ indirectly through ETA1 and ETA2 shows that the influence of dynamic ability (ETA1) on $\mathrm{ETA}_{3}$ is greater than competitive advantage (ETA2). Many experts argue that dynamic capability is a source of competitive advantage (Froehlich, Bitencourt, and Bossle, 2017; Ambrosini and Bowman, 2009; Teece, 2007). Eisenhardt and Martin (2000), Wheeler (2002), and Helfat et al (2007) argue that building dynamic capabilities of business organizations aims to create, expand or modify resources to achieve competitive advantage, so companies must attract, strengthen, and reconstruct. competitiveness becomes the same level as a dynamic business environment. Tight dynamic capabilities can be understood as the company's ability to renew its competence so as to achieve competitive advantage at any time and survive in the turbulence of the business environment $\mathrm{On}$ the other hand, the influence of $\mathrm{KSI}_{1}, \mathrm{KSI}_{2}$, and $\mathrm{KSI}_{3}$ indirectly through ETA1 and ETA2 shows that the influence of dynamic ability (ETA1) on ETA3 is greater than competitive advantage (ETA2). Many experts argue that dynamic capability is a source of competitive advantage (Froehlich, Bitencourt, and Bossle, 2017; Ambrosini and Bowman, 2009; Teece, 2007). Eisenhardt and Martin (2000), Wheeler (2002), and Helfat et al (2007) argue that building dynamic capabilities of business organizations aims to create, expand or modify resources to achieve competitive advantage, so companies must attract, strengthen, and reconstruct. competitiveness becomes the same level as a dynamic business environment. Tight dynamic capabilities can be understood as the company's ability to renew its competence so as to achieve competitive advantage at any time and survive in the turbulence of the business environment

The various factors above affect the management of workforce talent (ETA3), and ETA3 subsequently have an impact on job satisfaction (ETA4), performance (ETA5), and commitment to work continuity (ETA6). From the results of data analysis, it appears that ETA3 had the highest impact on ETA4, followed by ETA5, and then ETA6. That is, talent management that seeks to shape employee competencies must bring a level of job satisfaction to employees, which in turn will lead to improved performance and commitment to work continuity in the company concerned. Employee talent management tends not to provide optimal benefits if it does not bring employee job satisfaction, especially in adjusting income, rewarding achievements, increasing confidence in employees for the implementation of work, and providing other incentives. If not, the goal of managing employee talent will not bring progress to the company, and less inculcation of strengthening the commitment to work sustainability and ready to move to new jobs that are considered to have better prospects. 


\subsection{Contribution of Indicators}

Based on the results of structural testing it can be seen the contribution indicators to variables studied are shown in table 5 .

Table 5: Contribution of Indicators

\begin{tabular}{|c|c|c|c|c|}
\hline Variables & Indicators & Loading value & Construct Coef. & Contribution \\
\hline Culture Organization (KSI1) & $\begin{array}{l}\text { X1 }=\text { Futuristic } \\
\text { x2 }=\text { Discipline } \\
\text { x3 }=\text { Hard work } \\
\text { x4 }=\text { Reward system }\end{array}$ & \begin{tabular}{|l|}
0.15 \\
0.20 \\
0.09 \\
0.16 \\
\end{tabular} & \begin{tabular}{|l|}
0.92 \\
0.95 \\
0.90 \\
0.92 \\
\end{tabular} & \begin{tabular}{|l|}
0.1380 \\
0.1900 \\
0.0810 \\
0.1472 \\
\end{tabular} \\
\hline Transformational Leadership (KSI2) & \begin{tabular}{|l}
$\mathrm{x} 5=$ Visioner \\
$\mathrm{x} 6=$ Agent of Changes \\
$\mathrm{x} 7=$ Take risks \\
$\mathrm{x} 8=$ Transparant-democratic
\end{tabular} & $\begin{array}{l}0.13 \\
0.20 \\
0.17 \\
0.22 \\
\end{array}$ & $\begin{array}{l}0.93 \\
0.90 \\
0.91 \\
0.88 \\
\end{array}$ & $\begin{array}{l}0.1209 \\
0.1800 \\
0.1547 \\
0.1936 \\
\end{array}$ \\
\hline Division of Work (KSI3) & $\begin{array}{l}\mathrm{x} 9=\text { Work condition } \\
\mathrm{x} 10=\text { Job description } \\
\mathrm{x} 11=\text { Work relationship } \\
\mathrm{x} 12 \text { = Trust }\end{array}$ & $\begin{array}{l}0.08 \\
0.29 \\
0.08 \\
0.13 \\
\end{array}$ & $\begin{array}{l}0.96 \\
0.84 \\
0.96 \\
0.93\end{array}$ & $\begin{array}{l}0.0768 \\
0.2436 \\
0.0768 \\
0.1209\end{array}$ \\
\hline Dinamic Capability (ETA1) & $\begin{array}{l}\text { X13 }=\text { Sensing capability } \\
\text { x14 = Learning ability } \\
\text { x15 }=\text { Coordinating }\end{array}$ & $\begin{array}{l}0.32 \\
0.29 \\
0.25\end{array}$ & $\begin{array}{l}0.83 \\
0.84 \\
0.86\end{array}$ & $\begin{array}{l}0.2656 \\
0.2436 \\
0.2150\end{array}$ \\
\hline $\begin{array}{l}\text { Competitiveness Advantage } \\
\text { (ETA2) }\end{array}$ & $\begin{array}{l}\mathrm{x} 16=\text { Cost advantage } \\
\mathrm{x} 17=\text { Product differentiation } \\
\mathrm{x} 18=\text { Market segment }\end{array}$ & $\begin{array}{l}0.28 \\
0.29 \\
0.26\end{array}$ & $\begin{array}{l}0.85 \\
0.84 \\
0.86\end{array}$ & $\begin{array}{l}0.2380 \\
0.2436 \\
0.2236\end{array}$ \\
\hline $\begin{array}{l}\text { Employee Talent Management } \\
\text { (ETA3) }\end{array}$ & $\begin{array}{l}\text { X19 }=\text { Talent identification } \\
\text { X20 }=\text { Education and training } \\
\text { X21 = Work placement } \\
\text { X22 = Facilities support }\end{array}$ & $\begin{array}{l}0.25 \\
0.36 \\
0.14 \\
0.16 \\
\end{array}$ & $\begin{array}{l}0.87 \\
0.80 \\
0.92 \\
0.92\end{array}$ & $\begin{array}{c}0.2175 \\
0.2880 \\
0.1288 \\
0.1472\end{array}$ \\
\hline $\begin{array}{l}\text { Job Satisfaction } \\
\left(\mathrm{ETA}_{4}\right)\end{array}$ & $\begin{array}{l}\mathrm{x} 16=\text { Income level } \\
\mathrm{x} 17=\text { Career certainty } \\
\mathrm{x} 18=\text { Fullfilment of rights }\end{array}$ & $\begin{array}{l}0.55 \\
0.37 \\
0.26 \\
\end{array}$ & $\begin{array}{l}0.67 \\
0.79 \\
0.86\end{array}$ & $\begin{array}{l}0.3685 \\
0.2923 \\
0.2236\end{array}$ \\
\hline Job Performance (ETA5) & $\begin{array}{l}\text { x16 = Quantity } \\
\text { x17 = Quality } \\
\text { x18 = Punctuality }\end{array}$ & $\begin{array}{l}0.13 \\
0.27 \\
0.17\end{array}$ & $\begin{array}{l}0.93 \\
0.86 \\
0.91\end{array}$ & $\begin{array}{l}0.1209 \\
0.2322 \\
0.1547\end{array}$ \\
\hline $\begin{array}{l}\text { Commitment Sustainability } \\
\text { (ETA6) }\end{array}$ & $\begin{array}{l}\text { x16 }=\text { Loyalty } \\
\text { x17 }=\text { Work passion } \\
\text { x18 }=\text { Productivity }\end{array}$ & $\begin{array}{l}0.30 \\
0.09 \\
0.28\end{array}$ & $\begin{array}{l}0.84 \\
0.96 \\
0.85\end{array}$ & $\begin{array}{l}0.2520 \\
0.0864 \\
0.2380\end{array}$ \\
\hline
\end{tabular}

Source: Study impact of employee talent management

\section{Discussion}

Cultural organization (KSI1), transformational leadership (KSI2), and division of labor (KSI3) are exogenous variables that have a positive influence on dynamic ability (ETA1), competitive advantage (ETA2), and employee talent management (ETA3) as endogenous variables. Judging from the indicators contained in each variable, it appears that the discipline indicator (x2) contributes the highest value of 0.1900 to the cultural organization variable (KSI1), followed by the indicator of hard work implementation ( $\left.\mathrm{x}_{4}\right)$ of 0.1472 , a futuristic indicator for see the future achieving better results (x1), and indicators for implementing a reward system $\left(\mathrm{x}_{3}\right)$ of o.0810. In this result it shows that discipline is the main element that must be contained in the organization's corporate culture and must be obeyed by workers. Discipline related to self-control behavior in complying with applicable regulations in the company, both attendance, implementation of duties and functions, as well as 
timeliness of completion of work. Discipline will produce work behavior that is efficient, effective and productive. In this discipline also includes aspects of hard work or vice versa of workers with achievements in accordance with their behavior. Of course, disciplined behavior and hard work are also influenced by the orientation of the company's vision and goals and the application of rewards to be received by workers.

In the transformational leadership variable (KSI2), indicators that contribute the highest value are transparency and democratic attitudes of leaders (x8) of 0.1936 , followed by indicators of ability as agents of change (x6) of 0.1800 , indicators of courage to take risks to make changes $\left(\mathrm{x}_{7}\right)$ of 0.1547 , and visionary $\left(\mathrm{x}_{5}\right)$ of 0.1209 . For employees to see leadership in the company more emphasis on attitudes and behaviors of openness and democratic leadership, because it will be felt directly than with the visionary leadership. It is difficult for employees whether the leader is visionary or vice versa, unless involved and asked for input in making decisions about the direction and objectives of the company, and the ability of leaders to make changes and courage to use new methods or techniques to achieve better results. Especially the last one a leader must dare to try and risk failure, make the experience to make continuous improvements to achieve success.

Next, the division of labor ( $\left.\mathrm{KSI}_{3}\right)$. Indicators that contributed the highest value to $\mathrm{KSI}_{3}$ were job descriptions (x10) of 0.2436 , followed by trust indicators (x12) of 0.1209 , indicators of working conditions (x9) and work relations (x11) of 0.0768 respectively. In these variable employees tend to state the need for job descriptions in the form of systematic and clear job descriptions of the tasks and responsibilities of certain positions to carry out the work correctly and not overlap with each other. On the other hand, employees will work diligently and responsibly if they get the full trust of their leaders, and are supported by conducive working conditions and relation-ships (Flippo, 1989; Gomes, 2003; Stone, 2005; Hariandja, 2007).

$\mathrm{KSI}_{1}, \mathrm{KSI} 2$, and $\mathrm{KSI}_{3}$ have a direct positive effect on the dynamic capability variable (ETA1) and ETA1 $_{1}$ has a positive effect on the employee talent management variable (ETA3). Indicators that contributed the highest value to ETA1 were sensing capability ( $\mathrm{x}_{3}$ ) of 0.2656 , followed by learning capability indicator (x14) of 0.2436 , and coordinating indicator (x15) of 0.2150 . Sensing capability is the sensing ability to recognize, interpret, and pursue opportunities in an environment with competitive advantage and performance. Through sensing capabilities, companies will sense, anticipate and respond to the environment quickly by absorbing new knowledge, integrating internal and external resources, and formulating competitive advantages to seize markets and take profits. However, it will not be optimal if it is not accompanied by the company's learning ability to produce new knowledge, increase the value of organizational routines and be difficult to imitate and replace (non-substitutable) by competitors. In addition, it also requires the ability to coordinate all internal and external resources, synergistically and integrated to support the progress of the company (see: Kogut and Zander, 1992; Zollo and Winter, 2002; Pavlou and Sway, 2011)

$\mathrm{KSI}_{1}, \mathrm{KSI}_{2}$, and $\mathrm{KSI}_{3}$ have a direct positive effect on the Competitiveness Advantage (ETA2) and ETA2 have a positive effect on the employee talent management variable (ETA3). Indicators that contributed the highest value to the ETA2 variable were product differentiation (x17) of 0.2436 , followed by a cost advantage indicator (x16) of 0.2380 , and target market segment (x18) of 0.2236 . These results indicate that a company's superiority is not due to its strength in funding compared to competitors, but must emphasize product differentiation that reflects the difference with competitors' results. Product differentiation can constitute more value in capturing market segments (Kotler, 2000; Beath and Katsoulacos, 1991; Blokdyk, 2019). Even in the current competitive era Trout (2001) argues that a company needs product differentiation if it does not result in its death.

All variables (KSI1, $\mathrm{KSI}_{2}, \mathrm{KSI}_{3}, \mathrm{ETA}$, and $\mathrm{ETA}_{2}$ ) have a positive influence on employee talent management $\left(\mathrm{ETA}_{3}\right)$. From the ETA3 variable, the indicators that contributed the highest value were education and training (x20) of 0.2880 , followed by talent identification indicators (x19) of 0.2175 , facility support indicators (x22) of 0.1472 , and work placement (x21) amounting to 0.1288. In particular, education and training activities are a major aspect of employee talent management. Through education and training, workers as assets and company resources need to be managed 
according to their talents properly in order to be competent in carrying out the tasks assigned. With talent management employees will increasingly provide great opportunities for companies to achieve the success of the goals set (ilmumanajemensdm.com, 2018)). On the other hand, employee talent management requires steps to identify employee talent, prepare facilities needed to develop competencies and expertise, and accuracy in placement after getting education and training activities.

Talent management basically aims to develop worker competencies. This study found that talent management has an influence on workers, especially in terms of job satisfaction (ETA4), performance (ETA5), and commitment to sustainability (ETA6). From the job satisfaction variable (ETA4), the indicator that has the highest contribution value is the level of employee income (x16) of 0.3685 , followed by career certainty indicator $(\mathrm{x} 17)$ of 0.2923 , and fulfillment of rights (x18) of 0.2236 . These results indicate that the development of worker resources through talent management must bring increased income and worker satisfaction. If not, it will only bring an attitude of doubt and dissatisfaction with workers, so they do not see the benefits for themselves and the progress of the company. On the other hand talent management will also bring employee satisfaction if there is certainty in improving work careers and the fulfillment of guarantees of other rights, for example: payment of excess work hours, annual leave, health insurance, and others.

Another impact of talent management is on employee performance (ETA5). In this ETA5 variable, the indicator that contributed the highest value was work quality (x17) of 0.2322 , followed by an indicator of timeliness (x18) of 0.1547 , and the quantity of work (x16) of 0.1209. Arnold and Feldman (1986) and Robbins (2006) suggest that performance is a series of individual behaviors and activities in accordance with organizational expectations or goals. The results of this study indicate that talent management has an impact on the quality of work of workers, carrying out work according to schedule, and increasing the quantity of work. However, Colquit et al. (2014) said, improving employee performance is not only determined by the development of employee talent, but needs to be supported by job satisfaction and pleasure in doing work.

Talent management also positively influences workers' sustainability commitments (ETA6). In this ETA6 variable, the indicators that contribute the highest value are employee loyalty (x16) of 0.2520 , followed by indicators of work productivity (x18) of 0.2380 , and passion of work (x17) of 0.0864. Meyer \& Natalie (2002), Robbins (2011), Colquitt et al. (2014), Luthans (2002), Mowday (1998), Schermerhorn Jr (2010), Gibson et al (2015), and Cooper (2011) put forward the concept of organizational commitment is a condition of employees who have commitment and support the goals and outlooks of the organization. One type of organizational commitment is an ongoing commitment that is the desire to survive or leave the company. The strength of ongoing commitment will bring workers to continue working, because the company is considered useful in meeting their needs. This situation tends to arouse employee loyalty, enthusiasm, and high productivity, because the company is considered able to provide hope to improve welfare. Meyer and Natalie (2002) argue, someone who has a high desire to work has a reason to commit to the workplace because it is really comfortable and wants a job. At least that desire is caused by motivation for self and company progress, optimism for work and the future, confidence in career advancement, and strong work collaboration between colleagues to achieve common goals.

\section{Conclusion}

This study found that organizational culture, transformational leadership, and work division directly or indirectly through dynamic capabilities and competitive advantage have a positive effect on employee talent management. In direct influence transformational leadership has the highest positive influence on employee talent management rather than organizational culture and work division. The influence of leadership is related to the visionary view of achieving better results in the future, acting as agents of change, acting transparently and democratically, giving trust to employees, and developing togetherness to achieve company progress. In an indirect effect, dynamic capability 
has a greater influence on employee talent management than competitive advantage. On the other hand, employee talent management itself has an impact on job satisfaction, performance, and commitment to work sustainability.

On that basis efforts to develop employee talent must pay attention to the various variables mentioned above. Talent management also needs to pay attention to the indicators that contribute to each variable. Especially the application of employee talent management, will not have a positive impact if the benefits are not felt by workers, increase income, provide career certainty, fulfillment of guaranteed rights, work quality, timeliness, loyalty, work passion, and others.

\section{References}

Agung, I. (2010). Influence of Organizational Culture, Leadership, and Job Satisfaction on Teacher Performance in a School of Excellence in Jakarta's DKI Province, Dissertation, Jakarta State University.

Allen, N. J., \& Meyer, J. P. (1996.) Affective, Continuance, and Normative Commitment to the Organization: An Examination of Construct Validity, Journal of Vocational Behavior, Vol. 49(3), 252-276. doi.org/ o.1006/jvbe.1996.0043.

Amstrong, M. \& Baron, A, (2005), Managing Performance: Performance Management in Action. UK: CIPD Publishing.

Anderson, T. D. (2016). Transforming Leadership, New York Washington D.C: St. Lucie Press.

Arnold, H. J., \& Feldman, D. C, (1986), Organization Behavior. New York: McMillan.

Bakan, I., Buyukbese, T., Ersahan, B., Sezer, B (2014) Effects of Job Satisfaction on Job Performance and Occupational Commitment, International Journal of Management \& Information Technology, Vol. 9 (1), 1472 - 148o. DOI: 10.24297/ijmit.v9i1.668.

Bashori, K (2012) Talent Management for Optimizing the Productivity of Civil Servants, Journal of Policy and Management of Civil Servants, Vol. 6(2), 61-73. file:///G:/Journal_Maret/95-Article\%20Text -369-1-1020190221.pdf

Baum, T. (2002). Skills Training in the Hospitality Sector: A Review of Issues. Journal of Vocational Education \& Training, 54 (3), 343-63. doi.org/10.1080/13636820200204.

Beath, J., Katsoulacos, Y (1991) The Economic Theory of Product Differentiation, Cambridge University Press.

Blokdyk, G. (2019). Product Differentiation A Complete Guide, Publisher: 5 STARCooks.

Bharadwaj, S. G., Varadarajan, P. R., \& Fahy, J, (1993). Sustainable Competitive Advantage in Service Industries: A Conceptual Model and Research Propositions, Journal of Marketing, Vol. 57(4), 83-99. DOI: 10.2307/1252221.

Buchanan, J. M, (1977), Freedom in Constitutional Contract, Perspective of a Poltical Economist, London.

Cao, L. (2011). Dynamic Capabilities in a turbulent market environment: empirical evidence from international retailers in China, Journal of Strategic Marketing, Vol.19 (5).

Claudia, F. (2020). Division of Work in Management: Definition \& Explanation, Chapter 7, Lesson 24. https://study.com/academy/lesson/division-of-work-in-management-definition-lesson-quiz.html.

Cooper, D. J. (2011). Leadership for Follower Commitment. New York: Routledge.

Colquitt, J., Lepine, J. A., \& Wesson, M. J. (2014). Organizational Behavior: Improving Performance and Commitment in the Workplace (4e). New York, NY, USA: McGraw-Hill.

Dahl, R. L. (2003). Management, Jakarta: Gramedia.

Darmawati, A., Hidayati, L. N., \& Dyna, H. S. (2013). Effect of Job Satisfaction and Organizational Commitment on Organizational Citizenship Behavior, Economia Journal, Vol. 9 (1), 10-17. doi.org/10.21831/economia. v9i1. 1372

Day, G. S., \& Wensley, R. (1988). Assessing Advantage: A Framework for Diagnosing Competitive Superiority, Journal of Marketing, Vol. 52 (2), 1 - 20. http://doi.org/10.1177/002224298805200 201

Davis, S. M. (2004). Managing Corporate Culture, Cambridge Mass: Balinger Publishing Company.

Dixit, S., \& Arrawatia, M. A. (2018). The Impact of Talent Management on Job Satisfaction and Employee Performance in Public Sector Banks of Rajasthan, IJCRT Journal, Vol. 6 (1), 426 - 435 . http://www.ijcrt.org/papers/IJCRT1802489.pdf.

Eisenhardt, K. M., \& Martin. J. A. (2000). Dynamic Capabillities:what are they?, Strategic Management Journal, 21: 1105-1121. http://doi. org/10.1002/1097-0266.

Fatmasari (2017) Effect of Talent Management and Self Efficacy on the Performance of Weight Loss Distributor Employees, Darmajaya Business Journal, Vol. o3(o2), 89-105. file:///G:/ Journal_Maret/833-2410-1-PB.pdf.

Flippo, E. B. (1989). Personnel Management, Jakarta: Erlangga Publisher.

Gardner, H. E. (2006). Multiple Intelligences: New Horizons in Theory and Practice, Publisher BasicBooks. 
Gasperz, V. (2013). All-in-One Integrated Total Quality Talent Management: 50 Concepts, Models and Key Analyses in Total Quality, Practical Human Capital, and Talent Management System, Bogor: Tri-Al-Bros Publishing.

Gibson, J. L., Ivancevich, J. M., Donnelly, Jr. J. H., \& Konopaske, R. (2012). Organizations Behavior Structure Processes. New York: McGraw-Hill Companies.

Gomes, F. C. (2003). Human Resource Management, Jakarta: Andi Offset.

Hanna Viany Octavia, H. V., Susilo, H (2018) The Impact of Talent Management on Employee Performance (Study on Employees of PT Pertamina Geothermal Energy Area Ulubelu), Journal of Business Administration (JAB), Vol. 6o (2). 186 - 191. file:///G:/Journal_Maret/2524-10043-1-PB.pdf

Hasibuan, M. S. P. (2011). Human Resource Management, Jakarta: Bumi Aksara.

Haryono, S., \& Wardoyo, P. (2012). Structural equation modeling. Bekasi: PT Intermedia Personalia Utama.

Hidayat, H. S. (2018). Effect of Job Satisfaction on Organizational Commitment and Turnover Intention, Journal of Service Management and Marketing, Vol. 11 (1), 51 - 66. http://dx.doi.org/ 10.25105/jmpj.v10i1.2516.

https://journal.trunojoyo.ac.id/ecoentrepreneur/article/view/3033.

Ilmumanajemensdm.com. (2018). https://ilmumanajemensdm.com/strategipengembangan -manajemen- sdmberbasis-talenta/.

Irawati, S. A., Sudarsono, B., \& Lestari, L. (2017). The Effect of Talent Management and Human Resource Management on the Performance of Employees of PT Jawa Pos Media Televisi (JTV) in Surabaya, Surabaya Journal, 210 - 224. https://journal. trunojoyo.ac.id/ecoentrepreneur/article/view/ 3033 .

Kirkpatrick, T. O., \& Levis, C. T. (1995). Effective Supervision, New York: The Bryden Press.

Kogut, B., \& Zander, U. (1992). Knowledge of the Firm, Combinative Capabilities, and the Replication of Technology, Organization Science, Vol. 3(3). 383-397. Doi: 10.1287/ orsc.3.3.383.

Kotler, P. (200o). Marketing Management: The Millennium Edition, Publisher: Prentice Hall, Inc.

Lei, K. Y., Basit, A., \& Hasan, Z. (2018). The Impact of Talent Management on Job Satisfaction: A Study among the Employees of a Travel Agency in Malaysia, Indonesian Journal of Applied Business and Economic Research, Vol. 1 (1), 1 - 19. doi.org/10.32456/.vii1.6.

Luthans, F. (2002). The need for and meaning of positive organizational behavior. Journal of Organizational Behavior: The International Journal of Industrial, Occupational and Organizational Psychology and Behavior, 23(6), 695-706.

Mathis R. L., \& Jackson, J. H. (2006). Human Resources Management, Jakarta: Salemba Empat.

Ministry of Administrative and Bureaucratic Reform Republic of Indonesia. (2019). Government Prepares Talent Management. https://www.Menpan.go.id/site/berita-terkini/pemerintah-siapkanma najemen-talenta.

Meyer, J. P., \& Natalie J. A. (2002). Commitment in the Workplace Theory Research and Application. California: Sage Publications.

Mowday, R. T., Lyman W. P., \& Richard M. (1998) Organizational linkages: The Psychology of Commitment, Absenteeism, and Turnover. San Diego, California: Academic Press.

Nanus, B (2001) Visioner Leadership, Jakarta: Prenhallindo.

Pavlou, P. A. \& Sway, O. A (2011) Understanding the Black Box of Dynamic Capabilities Management, Decision Sciences, Vol. 42(1), 239-273. doi.org/10.1111/j.1540-5915.2010. 00287.

Pennings, J. M (1992) Research in Organization Behavior, Vol. 14, Greenwich, CT: JAI Press.

Pettigrew, A. (2015). On Studying Organizational Culture, Administrative Science Quarterly, Vol. $24(4)$, 570 - 581. http://eureka.sbs.ox.ac.uk/1485/

Robbins, S. P. (2006). Essentials of Organization Behavior, New Jersey: Prentice-Hall International Inc.

Roring, F. (2017). Influence of Leadership, Job Sharing and Compensation on Employee Performance At PT Bank Danamon Branch Manado, Journal of Business Management and Innovation, Vol. 4 (3), 144 - 154. file://C:/Users/TOSHIBA/Downloads/17991-36287-1-SM.pdf.

Sathe, V. (1983). Implications of Corporate Culture: A Manager Guide's to Action, Organizational Dynamics, 4 23. file:///G:/ Journal_Maret/first-page-pdf.pdf

Schein, E. H. (2014). Organizational Culture and Leaderhip, San Fransico: Jossey-Bass publishers.

Shaju, M., \& Subhashini, D. (2017). A study on the impact of Job Satisfaction on Job Performance of Employees working in Automobile Industry, Punjab, India, Journal of Management Research, Vol. 9 (1), 117 - 130. DOI: 10.5296/jmr.v9i1.10420.

Schermerhorn Jr. J. R., Hunt, J.G., \& Osborn, R. N. (2010). Organizational Behavior. USA: University of Phoenix.

Silzer, R., \& Dowell, B. E. (2009). Strategy-Driven Talent Management: A Leadership Imperative, John Wiley and Sons.

Soetjipto, B. W. (1997). Measuring Business Performance Balanced Scorecard, Usahawan Journal, No. o6 (XXVI), 21-25. http://www.dunia esai.com/ekonomi/Ekoz2.htm. 
Stone. R. J. (2005). Human Resource Management, Australia: John Wiley \& Sons.

Thoha, M. (2008). Organizational Behavior: Basic Concepts and Applications, Jakarta: RajaGrafindo Persada Publisher.

Trout, J. (2001). Differentiate or Die: Survival in Our Era of Killer Competition, Publisher: Wiley.

Usman, H. (2006). Management: Theory, Practice, and Research Research, Jakarta: Bumi Aksara.

Vecchio, R. P. (1995). Organizational Behavior, Florida: The Dryden Press.

Weber, M. (1968). Bureaucrazy, in Economy and Society, New York: Mc. Millan

Werang, B. R. (2014). Effects of Principal Transformational Leadership, Teacher's Work Morale, and Job Satisfaction on SDN Teacher Performance in Merauke City. Journal of Cakrawala Pendidikan, Th. XXXIII (1), 128-137. DOI: doi.org/10.21831/cp. vii1.1869

Wibowo. (2007.) Performance Management, Jakarta: RajaGrafindo.

Winingsih, L. H., Agung, I., \& Sulistiono, A.A. (2020). Talent Management Based-Education: Indonesian Case. Mediterranean Journal of Social Sciences, Vol. 11(3), 79-94. DOI: https://doi.org/10.36941/mjss-2020-0032

Yohana, C., Dania, R. F. R., \& Prihandono, D. (2021). Study of the Influence of Education and Literation of Entrepreneurship in Vocational High Schools: Indonesian Case. Academic Journal of Interdisciplinary Studies, Vol. 10(1), 34. https://doi.org/10.36941/ajis-2021-0004

Yukl, G. (2012). Leadership: What is it. Cases in Leadership (3rd. ed. pp. 1-42). Thousand Oaks, CA: Sage.

Zakso, A., \& Agung, I. (2021). Impact of Student Learning at Home Prevent Pandemic Covid-19 in Indonesia. Academic Journal of Interdisciplinary Studies, Vol. 10(2), 228-239. DOI: https://doi.org/10.36941/ajis-20210053

Zollo, M., \& Winter, S. G. (2002). Deliberate Learning and the Evolution of Dynamic Capabilities, Organization Science, Vol. 13 (3), 339 - 351. https://www.jstor.org/stable/3086025. 